\title{
Yhteisnavetat ja kokonaisvaltainen johtaminen kilpailukyvyn lähteinä
}

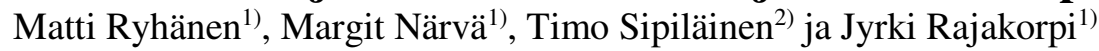

${ }^{1)}$ Seinäjoen ammattikorkeakoulu, SeAMK Elintarvike ja maatalous, Ilmajoentie 525, 60800 Ilmajoki, etunimi.sukunimi@seamk.fi

${ }^{2)}$ Helsingin yliopisto, taloustieteen laitos, PL 27,00014 Helsingin yliopisto, timo.sipilainen@helsinki.fi

\section{TIIVISTELMÄ}

Kokonaisvaltaisen johtamisen tavoitteena on hallita yritystoiminnan onnistumisen kannalta keskeisiä prosesseja ja toimintoja sekä tehdä niistä tehokkaasti ja kannattavasti toimiva kokonaisuus. Se on vision ja tahtotilan muodostamista siitä, millainen yritys on ja miten se toimii tulevaisuuden toimintaympäristössä. Se on strategisten valintojen tekemistä, operatiivista johtamista ja toimenpiteiden ja niitä tekevien toiminnan varmistamista. Artikkelissa tarkastellaan yhteisnavettojen yhteistyötä ja verkostoitumista kokonaisvaltaisen johtamisen näkökulmasta.

Teemahaastatteluihin valittiin yhteisnavettahanketta suunnittelevia, alle kolme ja yli kymmenen vuotta yhteisnavettayrittäjinä toimineita. Näin saatiin kuva, millaisia haasteita yhteisnavettayrittäjät olivat eri vaiheissa kohdanneet. Menetelmänä käytettiin laadullis-induktiivista analyysiä. Empiirisestä aineistosta lähtien induktiivisella päättelyllä tuotettiin tietoa yhteisnavetan ja yhteistyöverkoston olemuksesta.

Yhteisnavettayrittäjät olivat fuusioineet maidontuotannon. Omat tilat toimivat sopimustiloina. Kasvinviljelyä oli integroitu ajan myötä palvelemaan yhteisnavettaa ja koko yhteistyöverkostoa. Se olisi kannattanut tehdä heti, jolloin toiminta olisi ollut alusta lähtien tehokasta. Strateginen ajattelu ja kilpailuedun tavoittelu tulivat selkeästi esille. Yhteisnavetan perustaminen ja yhteistyöverkoston rakentaminen oli ollut selkeä strateginen päätös, vaikka systemaattinen ja määrätietoinen vision muodostaminen sekä strateginen suunnittelu ja johtaminen puuttuivat. Strategisella ajattelulla oli kuitenkin onnistuttu kyseenalaistamaan totuttu toimintatapa. Silti yhteisnavetan ja yhteistyöverkoston johtamisprosessia ei ollut rakennettu hallituksi kokonaisuudeksi. Johtaminen oli pääosin operatiivista. Liiketoimintamallia, jossa strategia muunnetaan käytännön toimiksi, ei ollut laadittu. Myös taloudelliset tavoitteet olivat jääneet taustalle. Maksuvalmiuden merkitystä korostettiin.

Yhteisnavetasta ja yhteistyöverkostoista voi tulla merkittävä kilpailutekijä, sillä ne mahdollistavat tehostamisen ja yksikkökustannusten alentamisen perinteiseen maidontuotantoon verrattuna. Kokonaisvaltaisella johtamisella saavutetaan kilpailuetua, kun osapuolet toimivat suunnitellusti osana yhteistyöverkostoa ja ymmärtävät velvoitteensa, vastuunsa ja sopeuttavat toimintansa yhteistyöverkostoa palvelevaksi. Yhteisnavettayrittäjät totesivat menneisyyttä tarkastellessaan, että asioita olisi voinut tehdä paremmin kuin he aikoinaan osasivat edes ajatella. Saman havainnon he tekivät asiantuntijoiden ja virkamiesten ohjeiden osalta. Jos yhteisnavettojen perustamista halutaan nopeuttaa, tarvitaan aktiivisia kehittämistoimia, sillä syvällisen yhteistyön oma-aloitteinen kehittäminen oli kestänyt kauan.

Asiasanat: yhteistyö, strategia, kilpailuetu, luottamus, teemahaastattelu 


\section{Johdanto}

Maidontuotannon kilpailuympäristön muuttuessa maidontuottajat joutuvat pohtimaan uusia ratkaisuja kannattavan tuotannon saavuttamiseksi. Maidontuottajan on kyettävä strategiseen ajatteluun eli hänen on pystyttävä ajattelemaan tulevaisuutta ja nähtävä sinne (vrt. Mintzberg 1991). Maitotiloja on johdettava kokonaisuutena. Strategisen ajattelun, suunnittelun ja johtamisen merkitys korostuu kilpailuympäristön muuttuessa ja maitotilojen koon kasvaessa. Yrityksen on mahdollista saavuttaa kilpailuetua markkinoilla joko tuotteita erilaistamalla tai kustannusjohtajuudella (vrt. Porter 1985, 24). Maidontuottajalle strategiseksi vaihtoehdoksi jää kustannusjohtajuus, koska meijerit odottavat tasalaatuista, sovitut laatukriteerit täyttävää maitoa. Maidon hinta määräytyy meijerin maksukyvyn ja/tai markkinatilanteen mukaan. Maidontuottajan näkökulmasta laatukriteerit ja hinta tulevat annettuina, jolloin maitotilan kannattavuuteen voidaan vaikuttaa yksikkökustannusten alentamisella.

Yksikkökustannusten alentamiseksi on yleensä kasvatettu tilakokoa. Perinteisesti toimiva maidontuottajaperhe on itsellinen. Pyykkösen ja Tiilikaisen (2009) mukaan itse tekeminen on yleistä maatiloilla, joilla on päätoimisesti työllistynyt yksi tai kaksi henkilöä. Osa maidontuottajista on lähtenyt kehittämään yritystoimintaansa perinteisestä tavasta poiketen. He ovat yhdistäneet liiketoimintansa yhteisnavetaksi. Yhteisnavetat ovat pisimmälle menevä yhteistyön muoto maidontuotannossa. Keskittyminen ydintoimintaan eli maidontuotantoon mahdollistuu, kun yhteisnavettayrittäjät tekevät yhteistyötä ja verkostoituvat muiden yrittäjien ja kumppanien kanssa. Strategisen liikkeenjohdon näkökulmasta hyvin johdettu yhteistyö mahdollistaa kilpailuedun saavuttamisen.

Tässä artikkelissa tarkastellaan yhteisnavettayrittäjien yhteistyötä ja verkostoitumista kokonaisvaltaisen johtamisen näkökulmasta. Tutkimuksessa haetaan vastausta kysymykseen: Miten yhteisnavetan ja sen yhteistyöverkoston kokonaisvaltainen johtaminen on toteutettu?

Kokonaisvaltainen johtaminen ja strateginen johtaminen ovat toisiaan lähellä olevia käsitteitä. Tässä artikkelissa käytetään käsitettä kokonaisvaltainen johtaminen korostamaan sitä, että operatiivinen ja strateginen johtaminen muodostavat toisiaan tukevan kokonaisuuden. Kokonaisvaltaisen johtamisen tavoitteena on hallita yritystoiminnan onnistumisen kannalta keskeisiä prosesseja ja toimintoja sekä tehdä niistä tehokkaasti ja kannattavasti toimiva kokonaisuus. Se on vision ja tahtotilan muodostamista siitä, millainen yritys on ja miten se toimii tulevaisuuden toimintaympäristössä. Se on strategisten valintojen tekemistä, operatiivista johtamista ja toimenpiteiden ja niitä tekevien toimintojen varmistamista.

Tässä artikkelissa (Kuvio 1) tarkastellaan yhteisnavettayrittäjien keskinäistä yhteistyötä sekä heidän verkostoitumistaan ja yhteistyötään kumppaneiden kanssa. Tarkastelu tapahtuu pääosin strategisesta näkökulmasta. Tuotantoteorian mukaisesti oletetaan, että yhteisnavetan ja sen yhteistyökumppaneiden tavoitteena on kustannustehokas tuotanto. Liiketaloudellisiksi tavoitteiksi oletetaan kannattavuuden ja taloudellisen tuloksen parantaminen sekä maksuvalmiudesta ja vakavaraisuudesta huolehtiminen.

Kuvion 1 mukaisesti yhteisnavettayrittäjien strategisen ajattelun on oltava yhtenevää. Heidän on yhdessä päätettävä yritystoimintansa arvot, visio ja toiminta-ajatus sekä sovitettava yhteen omat tavoitteet muiden yhteisnavettayrittäjien tavoitteiden kanssa. Yhteisnavetan strategia laaditaan kokonaisuuden tasolle ja tarvittaessa sitä täydennetään mahdollisten muiden yhteistyökumppaneiden strategioiden kanssa yhteensopivaksi (Ryhänen \& Laitila 2014). Strategia on vietävä käytäntöä palvelevaksi liiketoimintamalliksi eli toimintasuunnitelmaksi strategian toteuttamiseksi.

Yhteisnavettayrittäjät hankkivat yhdessä navetan sekä koneet ja kaluston. Sen lisäksi heidän on hankittava vielä peltoa ja eläimiä sekä järjestettävä kasvinviljely tukemaan maidontuotantoa. Yhteisnavettayrittäjillä, kuten muillakin yritystoimintaa kehittävillä maidontuottajilla on rajalliset resurssit. Peltoa, pääomaa, työvoimaa ja osaamista tarvitaan lisää. Menestymisen kannalta on oleellista, miten ja mihin yhteisnavettayrittäjät käyttävät rajalliset resurssinsa. Yhteisnavettayrittäjille, kuten muillekin maatalousyrittäjille, ongelmallista on voimavarojen liiallinen hajauttaminen eri toimintoihin, jolloin ne eivät ole tuottavimmassa käytössä. Yhteisnavettayrittäjät eivät selviä kaikista toimista omin voimin parhaalla mahdollisella tavalla. Haasteena on keskittyä ydinliiketoimintaan eli maidontuotantoon.

Verkostoitumisen keskeisenä ajatuksena on yrittäjän keskittyminen omalle ydinosaamisalueelle (Valkokari, Hakanen \& Airola 2007, 4). Maidontuottajat voivat yhteisnavettaa perustaessaan kohdentaa resurssinsa uudelleen ja tarkastella yhteistyösuhteiden rakentamista "puhtaalta pöydältä". Se mahdollistaa uusien näkökulmien muodostamisen ja riittävän määrän vaihtoehtoja, joista valinta tehdään (vrt. Kamensky 2010). Yhteistyökumppanit voivat toteuttaa ydinliiketoimintaa tukevan osaprosessin tai prosesseja voidaan ulkoistaa laajassa mitassa, jolloin syntyy yhteistyöverkosto. Yhteistyö ja verkostoituminen mahdollistavat yhteisnavettayrittäjien keskittymisen ydinosaamiseensa eli maidontuotantoon. 
Laitilan ym. (2014) mukaan maidontuottajilla on useita yhteistyösuhteita, jotka muodostavat yhdessä laajojakin verkostoja. Sopivasti liittoutumalla yhteisnavettayrittäjät voivat saavuttaa erikoistumisen ja suuruuden ekonomian tuomia hyötyjä. Eri yhteistyömuotoja ja -vaihtoehtoja hyödyntämällä ja ulkopuolisen osaamisen käytöllä yhteisnavettayrittäjät voivat helpottaa työvoiman ja pellon hankintaa sekä pääomarakenteen hallintaa (Ryhänen \& Laitila 2014).
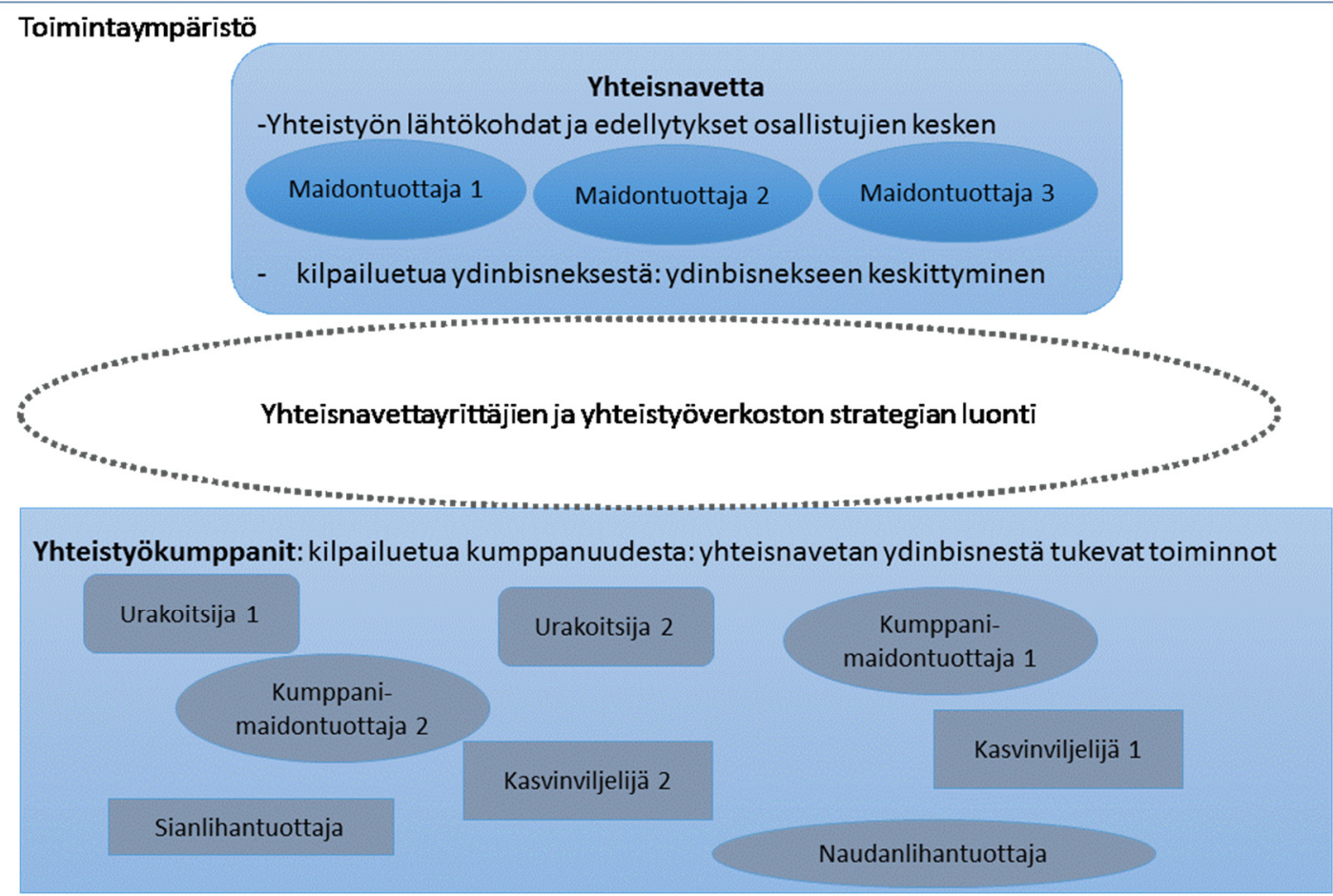

Kuvio 1. Yhteisnavetan ja yhteistyöverkoston kokonaisvaltaisen johtamisen kehikko (vrt. Ryhänen ym. 2015).

Yhteisnavetan ja yhteistyöverkoston luonnin lähtökohtana on toimintaympäristön, erityisesti markkinoiden ja maatalouspolitiikan, nykytilan tuntemus sekä tulevaisuuden muutosten ennakointi. Strategian luontia ohjaa tavoite saavuttaa kilpailuetua ydinliiketoimintaan keskittymisestä. Yhteistyön suunnittelu edellyttää kokonaisvaltaista näkemystä, miten yhteisnavettaa ja yhteistyösuhteita johdetaan kokonaisuutena. Yhteisnavettayrittäjien ja yhteistyökumppaneiden yhteisessä strategiatyössä päätetään, mitä yhteistyöverkoston prosesseja ja toimintoja toteutetaan yhdessä, mitä yhteisnavettayrittäjät tekevät itse, mitä yhteistyökumppanit tekevät ja mitä osaprosesseja ja toimintoja ulkoistetaan. Yhteistyöstrategian toteuttamisella tavoitellaan toiminnan tehokkuutta koko yhteistyöverkoston tasolla. Yhteisnavetan ja yhteistyökumppaneiden muodostaman verkoston tarkasteleminen kokonaisuutena on oleellista, sillä yhteistyön käynnistäminen tai laajentaminen tietyssä prosessissa tai toiminnossa vaikuttaa yleensä myös muihin prosesseihin ja/tai toimintoihin. Kokonaissuunnittelussa päätetään myös johtamisesta. Vaikka yhteistyö ja verkostoituminen perustuvat kumppanuuteen ja päätökset edellyttävät konsensusta, monenkeskinen yhteistyö vaatii johtajuutta. Määrätietoinen toiminta ilman johtajuutta on käytännössä mahdotonta (Hakanen, Heinonen \& Sipilä 2007).

\section{Aineisto ja menetelmät}

Yhteisnavetat eivät ole yleistyneet Suomessa ja niistä on olemassa vain rajallisesti tutkimustietoa. Tutkimus toteutettiin kvalitatiivisella tutkimusotteella. Tutkimuksessa kartoitettiin tutkittavaa aihealuetta ja haettiin tietoa yhteisnavetoiden ja niiden yhteistyöverkostojen kokonaisvaltaisesta suunnittelusta. (vrt. Metsämuuronen 2009, 243-246.) Aineisto kerättiin teemahaastatteluin, joihin haastateltaviksi valittiin yhteisnavettahanketta suunnittelevia, alle kolme ja yli kymmenen vuotta yhteisnavettayrittäjinä toimineita. Tutkimusaineisto sisältää yhteensä viisi teemahaastattelua, joista kaksi tehtiin yhteisnavettahanketta suunnitteleville maatalousyrittäjille, kaksi alle kolme vuotta yhteisnavettayrittäjinä toimineille ja 
yksi yli kymmenen vuotta yhteisnavettayrittäjinä toimineille. Haastattelut toteutettiin kevään ja alkukesän 2015 aikana. Haastattelut nauhoitettiin ja litteroitiin heti haastattelujen jälkeen.

Analyysi ja tulkinta tehtiin laadullis-induktiivisesti eli yksityiskohdista liikkeelle lähtien tiivistettiin tutkimusongelmaan keskeisesti liittyvät tekijät ja etsittiin niille tulkinta (vrt. Hirsjärvi, Remes \& Sajavaara 2007, 160). Tutkimustuloksia ei voida yleistää, mutta ne ovat siirrettävissä hyödyttämään uusien yhteisnavettojen ja yhteistyöverkostojen suunnittelua, perustamista ja johtamista.

\section{Tulokset}

\section{Yhteisnavetan suunnittelu ja kokonaisvaltainen johtaminen}

Yhteisnavettayrittäjät kokivat, että he eivät olisi erillisinä, yksin toimivina maidontuottajina kyenneet kehittämään yritystään ja kasvattamaan yrityskokoa tavoitteidensa mukaisesti. Yhteisnavetalla tavoiteltiin tuotannon tehostamista, yksikkökustannusten alentamista, yrittäjäkohtaisen työtaakan vähentämistä ja työn helpottumista, vapaa-ajan lisäämistä, riskien hallinnan parantamista sekä vastuun jakamista ja osaamispääoman kasvattamista.

Yhteisnavettayrittäjiksi oli valikoitunut henkilöitä, jotka halusivat tehdä yhteistyötä keskenään ja jotka olivat kokeneet toisensa luonteeltaan yhteistyöhön soveltuviksi ja luotettaviksi sekä henkilökemioiltaan sopiviksi. Yhteisnavettahankkeiden aloitteentekijät olivat esitelleet potentiaalisille yhteisnavettaosakkaille tavoitteita yleensä tuotantoon liittyvinä tavoitteina, taloutta oli ajateltu lähinnä kassavirran muodostumisen näkökulmasta. Ennen yhteisnavettahankkeen toteuttamispäätöstä systemaattista suunnittelua ei ollut tehty.

Yhteisnavettahankkeen toteuttamisen mahdollisti osallistujien yhtenevä strateginen ajattelu sekä riittävässä määrin yhteiset arvot ja yhteinen käsitys maidontuotannon kehittämisestä. Osallistujien toiveiden toteutumista yhteishankkeessa ei varmistettu erikseen. Vastuualueiden ja tehtävien jako oli koettu tärkeäksi ja näiden osalta kumppaneiden toiveiden toteutumisen varmistaminen koettiin onnistuneeksi. Tavoitteiden asettaminen ja varmistaminen oli painottunut operatiivisten toimien yhteensovittamiseen ja niiden toimivuuden tarkasteluun. Yhteisnavetan perustamisessa ja yhteistyössä pidettiin tärkeänä rehellisyyttä, luottamusta ja halua sitoutua yhteisiin tavoitteisiin.

Yhteisnavettaprojektin suunnittelussa ja toteutuksessa käytettiin vaihtelevasti ulkopuolista apua. Luotettavan ja osaavan suunnitteluavun saaminen koettiin haasteelliseksi. Yhteiskunnan taholta toivottiin selkeitä päätöksiä ja ohjeita. Yhteisnavettayrittäjät olivat joutuneet tekemään päätöksiä osin puutteellisten suunnitelmien, ohjeiden ja tietojen varassa.

Yhteisnavettayrittäjät pitivät yhteisnavetan johtamista haasteellisempana kuin maitotilan, jossa osakkaana on vain yksi yrittäjä/yrittäjäperhe. Usean osakkaan välinen yhteistyö vaatii yhteensovittamista. Haastatteluissa korostettiin jokapäiväisestä toiminnasta selviytymistä. Operatiiviseen johtamiseen oli kiinnitetty huomiota, mutta strateginen johtaminen oli jäänyt pääosin alustavien pohdintojen tasolle. Haastatelluilla on kykyä ajatella strategisesti. Sen sijaan systemaattinen strateginen suunnittelu ja johtaminen olivat suurelle osalle heistä vaikeasti hahmotettavissa olevia asioita. Toimintaympäristössä tapahtuneet muutokset olivat yllättäneet valtaosan yhteisnavettayrittäjistä, joten niihin ei ollut varauduttu riittävästi.

Käsitykset johtamisesta ja johtamisen tärkeydestä poikkesivat toisistaan. Mitä kauemmin yhteisnavetta oli toiminut, sitä tärkeämpänä johtamista pidettiin. Pitkän aikaa toimineessa yhteisnavetassa johtamisen merkitys koettiin tärkeäksi. Pitkän aikaa yhteisnavettayrittäjinä toimineiden mielestä yrityskokonaisuuden johtamisen merkitys korostuu yhteisnavetan toimintaa kehitettäessä, yrityskokoa kasvatettaessa ja vierasta työvoimaa palkatessa. Vähän aikaa yhteisnavettayrittäjinä toimineille yhteisnavetan johtamisen haasteet ja merkitys olivat alkaneet hahmottua kokemusten kautta. Heille johtamisesta oli tullut lähinnä maksuvalmiusperusteista johtamista. Suunnittuvaiheessa oleville johtamiskysymykset olivat alustavien pohdintojen ja keskustelujen tasolla.

\section{Yhteisnavetan yhteistyöverkoston kokonaisvaltainen johtaminen}

Yhteisnavettayrittäjien yhteistyö ja yhteistyöverkostot poikkesivat osin toisistaan. Säilörehunteko ja karjanlannan levitys oli pääsääntöisesti ulkoistettu urakoitsijoille. Muutoin kasvinviljely- ja sadonkorjuuprosessit oli järjestetty eri tavoin. Yhteistyötä ja urakointipalveluita oli hyödynnetty paljon rehuviljojen korjuussa, kylvö- ja muokkaustöissä sekä kasvinsuojelussa. Tulosten mukaan näyttää siltä, että 
mitä kauemmin yhteisnavetta on toiminut, sitä enemmän keskitytään ydinliiketoimintaan. Yhteisnavettaa suunnittelevat aikoivat viljellä peltojaan itse ja käyttää omia koneitaan kasvinviljelyyn. Vähän aikaa yhteisnavettayrittäjinä toimineet olivat vähentämässä kasvinviljelytöitään ja pitkän aikaa toimineet olivat yhä enemmän keskittymässä ydinliiketoimintaan.

Yhteisnavettayrittäjät pitivät ydinliiketoimintanaan maidontuotantoa. Ydinliiketoimintaa tukevia prosesseja oli pyritty tehostamaan yhteistyökumppaneiden avulla. Yhteistyökumppaneita oli kuitenkin alettu aktiivisesti hakea vasta sen jälkeen, kun yhteisnavetan toiminta oli jo alkanut. Yhteistyökumppaneille oli tullut tarvetta työmäärän kasvaessa isoksi. Yhteistyön laajetessa ja syventyessä yhteisnavetan riippuvuus yhteistyökumppaneista oli lisääntynyt. Samalla luottamus yhteistyökumppanien kykyyn ja haluun toimia yhdessä oli kasvanut.

Toimivan yhteistyön edellytyksenä pidettiin luottamusta ja kaikkien osapuolien hyötymistä yhteistyöstä. Haastatellut kokivat yhteistyön edut haittoja suuremmiksi. Oman päätäntävallan väheneminen ja omista toimintatavoista joustaminen koettiin osin epämiellyttäväksi mutta välttämättömäksi, jotta yhteistyö onnistuu. Yhteisnavettayrittäjät olivat tehneet yhteistyökumppaneidensa kanssa pääasiassa suullisia sopimuksia. Haastateltujen mukaan yhteistyöverkostojen laajentuessa jatkossa tarvitaan myös kirjallisia sopimuksia.

Haastatellut tiedostivat, että yhteistyökokonaisuutta on tarpeen johtaa. Yhteistyön lisääminen ja kehittäminen edellyttävät suunnittelua, jotta yhteistyöverkoston investoinnit voidaan toteuttaa ja ajoittaa oikein. Yhteisnavettayrittäjien ja heidän yhteistyökumppaneiden strateginen ajattelu oli ollut riittävästi yhtenevä ja heille oli syntynyt myös yhteinen strateginen näkemys yhteistyöverkoston toimintatavoista. Yhteistyöverkostolle ei kuitenkaan ollut laadittu kirjallista strategiaa ja käytännön liiketoimintamalli puuttui.

Pääosalle yhteisnavettayrittäjistä yhteistyöverkoston kokonaisvaltaisen johtamisen elementit olivat monilta osin vieraita. Yhteistyöverkoston tasolla strategisen suunnittelun ja johtamisen käytäntöön vienti koettiin haasteelliseksi. Valtaosa yhteistyökumppaneista on tottunut toimimaan lyhytjänteisesti operatiivisia toimia tehden. Samoin kuin yhteisnavetan kokonaisvaltaisessa johtamisessa myös yhteistyöverkoston kokonaisvaltaisessa johtamisessa oli eroja. Pitkän aikaa toimineessa yhteisnavetassa strategisen johtamisen merkitys on kasvamassa. Yhteistyökokonaisuuden kokonaisvaltaista suunnittelua ja johtamista oli pohdittu ja siihen tulevaisuudessa panostetaan, vaikka se koettiinkin haastavaksi. Yhteisnavettaa suunnitteleville yhteistyökokonaisuuden hahmottaminen oli vaikeaa ja he toivoivat apua pitkään toimineilta yhteisnavettayrittäjiltä.

Haastateltujen mukaan yhteistyökokonaisuuden kokonaisvaltainen johtaminen on tarpeen, mutta se on haastavaa. Onnistuminen edellyttää kouluttautumista ja uuden omaksumista sekä kaikkien osapuolten sitoutumista. Yhteisnavettayrittäjät kokivat ajan puutteen suurimmaksi haasteeksi suunnitteluja johtamistoimille. Heidän mukaansa operatiivisen tason neuvontaa oli ollut tarjolla runsaasti, mutta strategisen tason osaajat ja neuvonta oli selkeästi puutteellista.

\section{Johtopäätökset}

Yhteisnavetta on pisimmälle menevä yhteistyömuoto maidontuotannossa. Yhteisnavetan perustaminen vaatii osallistujilta uudenlaista ajattelutapaa. Heidän on kyseenalaistettava perinteinen, viljelijäperheen itsellinen yrittäminen ja oltava yhteistyökykyisiä ja -haluisia. Yhteisnavetoita on Suomessa vielä verrattain vähän. Yhteisnavettayrittäjät ovatkin olleet edelläkävijöitä. He ovat joutuneet tekemään isoja päätöksiä puutteellisten tietojen ja ohjeiden varassa. Yhteisnavettaa suunnittelevat toivovat voivansa hyödyntää yhteisnavettayrittäjien osaamista ja kokemuksia yhteisnavettaprojekteissaan.

Yhteisnavettaa suunnittelevat, vähän aikaa yhteisnavettaa pyörittäneet ja pitkän aikaa yhteisnavettayrittäjinä toimineet erosivat yhteisnavetan johtamisen osalta toisistaan. Yhteisnavettaa suunnitellessa ja toiminnan alkuvaiheessa johtaminen painottuu operatiivisiin asioihin. Lähinnä kiinnitetään huomiota osakkaiden keskinäiseen tehtävien ja vastuiden jakoon. Sen sijaan pitkän aikaa yhteisnavettayrittäjinä toimineet tiedostavat strategisen suunnittelun ja johtamisen tarpeen (vrt. Olson 2004). Haastateltavat kokevat maidontuotannon ydinliiketoiminnakseen ja hyödyntävät yhteistyökumppaneita maidontuotantoa tukevissa prosesseissa. Yhteisnavetan suunnitteluvaiheessa yhteistyöverkoston hahmottaminen on vaikeaa ja yhteistyökumppaneita aletaan hakea vasta toiminnan ollessa jo käynnissä. Pitkän aikaa yhteisnavettayrittäjinä toimineet haluavat kehittää yhteistyöverkoston kokonaisvaltaista johtamista ja luoda kestävän yhteistyöverkoston. Kokonaisvaltainen johtaminen on vastaajien mielestä 
haasteellista. Tällä hetkellä johtaminen painottuu operatiiviseen johtamiseen. Systemaattinen strateginen suunnittelu ja johtaminen koetaan vaikeaksi. Tähän ei ole ollut myöskään ulkopuolista osaamista riittävästi saatavilla.

Toimivasta yhteisnavetasta ja yhteistyöverkostoista voi tulla suomalaiselle maidontuottajalle merkittävä kilpailuetu, sillä ne mahdollistavat tuotannon tehostamisen ja yksikkökustannusten alentamisen perinteiseen maidontuotantoon verrattuna. Tämän tutkimuksen tulosten mukaan yhteisnavetan johtaminen on haasteellisempaa kuin perinteisen maitotilan. Strategisen johtamisen tarve on konkretisoitunut yhteisnavettayrittäjille vasta toiminnan alettua ja siihen liittyvän osaamisen hankkiminen koetaan vaativaksi tehtäväksi. Yhteisnavettayrittäjiksi aikoville ja yhteisnavettayrittämistä suunnitteleville tulisi tarjota tukea kokonaisvaltaisen johtamisen omaksumiseen, mikäli halutaan edesauttaa yhteisnavetoiden perustamista ja niiden toiminnan kehittämistä.

\section{Kirjallisuus}

Hakanen, M., Heinonen, U. \& Sipilä, P. 2007. Verkostojen strategiat. Menesty yhteistyössä. Helsinki: Edita. Hirsjärvi, S., Remes, P. \& Sajavaara, P. 2007. Tutki ja kirjoita. 13., osin uud. p. Helsinki: Kustannusosakeyhtiö Tammi.

Kamensky, M. 2010. Strateginen johtaminen - menestyksen timantti. Helsinki: Talentum.

Laitila, E., Ryhänen, M., Närvä, M., Sipiläinen. T. \& Rajakorpi, J. 2014a. Yhteistyö ja verkostomainen toimintatapa maidontuotannossa. Teoksessa: M. Ryhänen \& E. Laitila (toim.) Yhteistyö- ja verkostosuhteet. Strateginen tarkastelu maidontuotantoon sovellettuna. Seinäjoen ammattikorkeakoulu. Seinäjoen ammattikorkeakoulun julkaisusarja A. Tutkimuksia 19: 18-78.

Metsämuuronen, J. 2009. Tutkimuksen tekemisen perusteet ihmistieteissä. Tutkijalaitos. Jyväskylä: Gummerus.

Mintzberg, H. 1991. Strategic Thinking as "seeing". Teoksessa: J. Näsi (toim.) Arenas of Strategic Thinking. Helsinki: Foundation of Economic Education.

Olson, K. 2004. Farm management: principles and strategies. Ames, IA: Iowa State Press.

Porter, M. 1985. Kilpailuetu. Suomentaja Maarit Tillman. Espoo: Weilin \& Göös.

Pyykkönen, P. \& Tiilikainen, S. 2009. Töiden organisointi Suomen maataloudessa. PTT. raportteja 217.

Ryhänen, M. \& Laitila, E. (toim.) 2014. Yhteistyö ja verkostosuhteet. Strateginen tarkastelu maidontuotantoon sovellettuna. Seinäjoen ammattikorkeakoulun julkaisusarja A. Tutkimuksia 19: 1-204.

Ryhänen, M., Närvä, M., Sipiläinen, T. \& Rajakorpi, J. 2015. Yhteisnavetan perustaminen ja johtaminen. Teoksessa: T. Sipiläinen \& S. Lindberg (toim.) Maatilojen yhteistyö - esimerkkejä kotieläin- ja kasvintuotannon yhteensovittamisesta. Helsingin yliopisto. Taloustieteen laitos. Selvityksiä 82: 57-90.

Valkokari, K., Hakanen, T. \& Airola, M. 2007. Yritysverkoston strateginen kehittäminen. Työkirja. VTT.

Helsinki: Edita Prima Oy. 